\title{
The climatic and hydrological changes and environmental responses recorded in lake sediments of Xinjiang, China
}

\author{
Long $\mathrm{MA}^{1,2^{*}}$, JingLu WU², Jilili Abuduwaili ${ }^{1}$ \\ ${ }^{1}$ Xinjiang Institute of Ecology and Geography, Chinese Academy of Sciences, Urumqi 830011, China; \\ ${ }^{2}$ State Key Laboratory of Lake Science and Environment, Nanjing Institute of Geography and Limnology, Chinese Academy of \\ Sciences, Nanjing 210008, China
}

\begin{abstract}
Based on the analyses of environmental proxy data in lake sediments and instrumental records of Xinjiang in northwest China, the Holocene climate and hydrological variability and its environmental responses were studied in different time scales and regions. The results showed that the Holocene climate variability had obvious differences between the north and south of Xinjiang. In northern Xinjiang, the Holocene climate was dry in the early period, humid in the middle period, and then changed to dry in the late period. However, the climate transition times were not consistent in different regions. In southern Xinjiang, although there were many different types of climate change patterns inferred from different catchments, the warm and wet climate was recorded in most lake sediments in the middle Holocene. According to comparisons of some millennium scale records in lake sediments, the climate was warm and dry in the past 100 years. It can be concluded the climate showed a trend of aridity in Holocene. Especially in recent 50 years, the lake area has been shrinking rapidly because of the population growth and social economic development, which brings some environmental problems. Lake level and area changes were sensitively affected by the climate variation in geological history of Xinjiang and the lake level will continue to shrink because of the drought climate and strengthened human activities.
\end{abstract}

Keywords: Holocene; climate variation; lake level; lake sediment; arid environment

\section{Introduction}

In order to predict future climate change, we need to have a clear understanding of the past climate (Stanley, 2000). Lakes in arid areas are mostly closed and they are sensitive to climatic and environmental changes. Because lake sediments are composed of transported materials derived from the watershed and deposition due to the metabolism of the lake itself, they can provide rich information not only on the lake evolution but also on environmental change in the surrounding catchment (Engstrom and Wright, 1984; Stanley, 2000; Wu et al., 2009). Xinjiang Uygur Autonomous Region (shortened as Xinjiang below) locates in the arid northwest China, and the regional ecology is highly fragile. It definitely seems that future climate change will completely influence the subsistence and society abidance development of human beings. Based on our previous study and other results, we discussed the climate and environment change in arid Xinjiang since the Holocene. With a historical perspective of climatic and environmental change, we offer some theoretical and practical references on rational development, use and protection of water resources in arid northwest China.

\section{The outline of Xinjiang lakes}

Xinjiang Uygur Autonomous Region has a vast territory, with an area of $1.6 \times 10^{6} \mathrm{~km}^{2}$, and has complex geological structures. The Tianshan Mountains divide Xinjiang into northern and southern parts with very different climate and landscape. Southern Xinjiang includes the Tarim Basin, while northern Xinjiang

Received 2010-10-21; accepted 2010-11-22

doi: 10.3724/SP.J.1227.2011.00001

* Corresponding author: Long MA (E-mail: malong@live.cn) 
contains the Junggar Basin. The Kunlun Mountains are one of the longest mountain ranges in Asia, and forms the northern edge of the Tibetan Plateau in south of the Tarim Basin. Altun Mountains in southeastern Xinjiang separates the eastern Tarim Basin from the Tibetan Plateau. Altay Mountain is in northern Xinjiang, where China is neighbored with Russia, Mongolia and Kazakhstan. Influenced by geomorphology and climate, many types of lakes are distributed in Xinjiang (Fig. 1).

According to the research of Wang and Dou (1998), the number of lakes with an area greater than $1 \mathrm{~km}^{2}$ in Xinjiang is 137 , and the total area is $5,072 \mathrm{~km}^{2}$, which accounts for $7.1 \%$ of the entire lake area in China. In addition, the number of lakes with an area over $10 \mathrm{~km}^{2}$ is 32 (total area is $4,828 \mathrm{~km}^{2}$ ). According to water salinity, the lakes in Xinjiang are classified into four types: freshwater lakes, brackish lakes, salt lakes and playa lakes. Most of these lakes are located in closed or semi-closed basins and isolated with oceans. The lake water systems are generally short with poor river flow, and the lakes are always situated in the downstream of rivers. Because of the water consumption of drainage exploitation, some lake levels decreased rapidly and even dried up.

\section{Hydrological and climatic variations in Holocene}

From the perspective of the natural evolution, the drought history of Xinjiang reflected the evolution of water resources (Liu et al., 2004). The characteristics of climatic and environmental evolution generally varied in different time scales, but the climate change in large temporal and spatial scales will provide a background for future climate change. This study will help us to reveal the intensity, distribution, transformation and evolution characteristics of drought in Xinjiang.

\subsection{Holocene hydrological and climatic variations in northern Xinjiang}

Ebinur (Aibi) Lake is located in the western Junggar Basin of Xinjiang (Fig. 1). According to previous studies (Wu, 1995; Wu et al., 2003), generally Ebinur Lake had an oscillatory contraction process. In the early Holocene, the climate was dry with desert steppe cover, but the lake water was fresh, shallow and cool inferred from the ostracoda assemblage. The middle Holocene (8.3-3.5 ka BP) was a warmer and moist stage. Specially, between 7.3 to $6.4 \mathrm{ka} \mathrm{BP}$, it was a relatively stable humid temperate stage. In the late

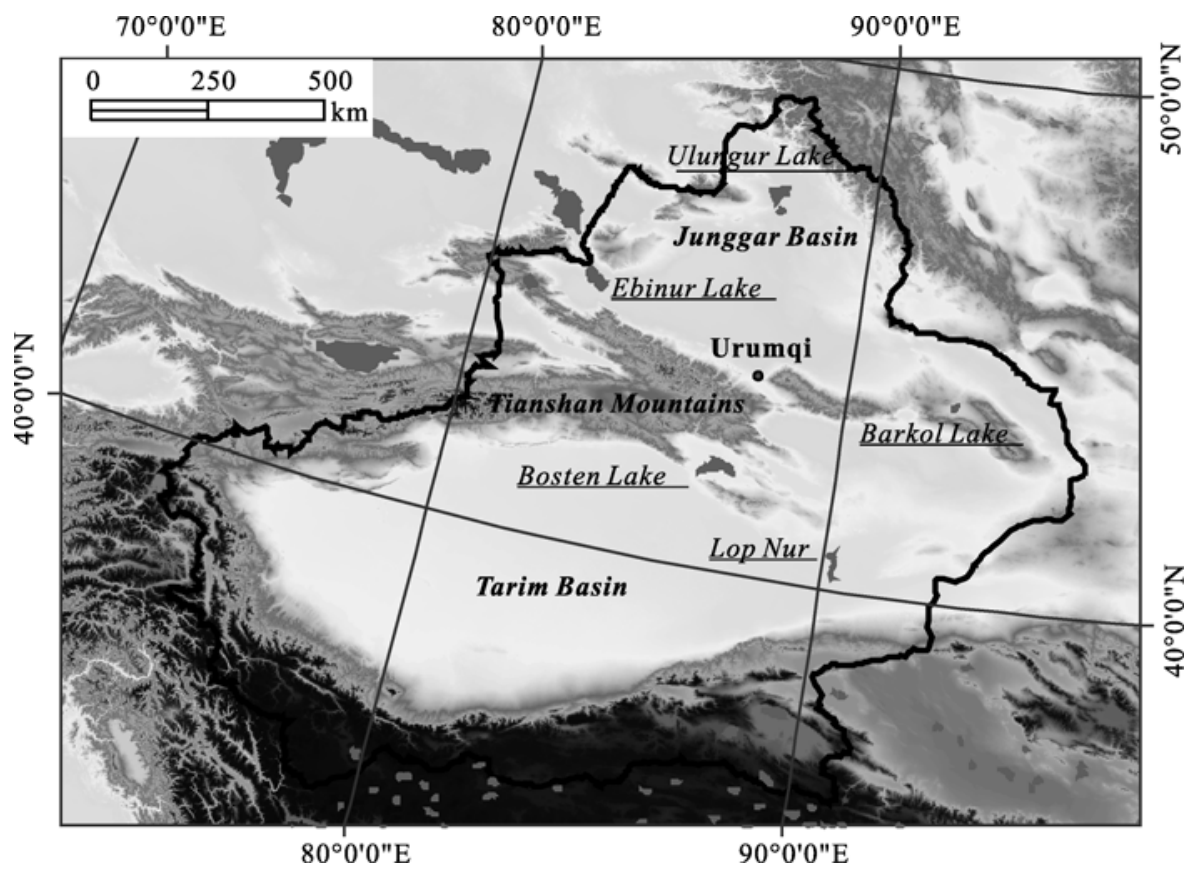

Fig. 1 Lakes distributed in different geomorphologic regions of Xinjiang 
Holocene (3.5 ka BP to present), the regional ground cover changed to desert steppe again, the climate was draught which was similar to the present climate inferred from the geochemical element contents. According to the comparisons of climatic and environmental proxy data inferred from lacustrine sediments of Ulungur Lake (Yang and Wang, 1994; Jiang et al., 2006; Xiao et al., 2006), Manas Lake (Rhodes et al., 1994; Sun et al., 1994; Lin et al., 1996), Barkol Lake (Han et al., 1992; Xue and Zhong, 2008) and Ebinur Lake (Wu, 1995; Wu et al., 2003), it showed that Holocene climatic and environmental change had an obvious consistency.

Since early Holocene, the water temperature of Ulungur Lake increased, which was indicated by the appeared ostracods of warm-brackish water assemblage (Yang and Wang, 1994). The lake level was shallow inferred from the poor sorting and higher skewness and kurtoisis values of the grain sizes in the lake sediment (Jiang et al., 2006). In the early Mid-Holocene (7.6-5.3 ka BP), Artemisia dominated the grassland vegetation (Yang and Wang, 1994). The better sorting of grain size and simple source of the lake sediment suggested a deep water environment (Yang and Wang, 1994). In the late Mid-Holocene, the regional climate showed a trend of warmer and dryer. Since the late Holocene, the lake sediments' grain-size characteristics reflected the overall water level downward trend. Between 3.6 to $1.24 \mathrm{ka} \mathrm{BP}$, the increased pollen flux and $\mathrm{A} / \mathrm{C}$ index showed a suitable climate, enhanced precipitation and increased lake water level. Since 1.24 ka BP, the smaller pollen A/C index, larger quantities of Pediastrum and increased pollen flux implied the relatively higher temperature and evaporation and lower lake water level (Xiao et al., 2006; Jiang et al., 2007).

In Manas Lake region, based on the analysis of $\delta^{18} \mathrm{O}$ in carbonate (Lin et al., 1996) and pollen record (Sun et al., 1994), the climate was suitable with increased pollen sediment rate and $\mathrm{A} / \mathrm{C}$ index. The negative $\delta^{18} \mathrm{O}$ values reflected the expanded lake area. In the late Mid-Holocene (6.0-4.2 ka BP), the ground cover was desert vegetation with decreased $\mathrm{A} / \mathrm{C}$ index and increased $\delta^{18} \mathrm{O}$ values, which showed the regional climate was dry. Since $4.2 \mathrm{ka} \mathrm{BP}$, the ground cover generally changed to steppe or desert steppe, which implied the climate was worse than Mid-Holocene.
But the lake area expanded between 4.2 to $2.5 \mathrm{ka} \mathrm{BP}$. During the period of 3.8-3.5 ka BP, the climate was short-lived drought with higher carbonate contents and lower organic matter contents (Rhodes et al., 1994). In the past century, the sediments were mainly composed of mineral crystals, and the climate was dry with developed desert vegetation.

Han et al. (1992) made systemic researches on Holocene climate change in Barkol Lake region and divided the Holocene into several warm-dry and cold-wet periods. Generally, the climate was dry in early Holocene with sparse vegetation. It was cold-wet in middle Holocene but was warm-dry in late Holocene. Based on the study of Xue and Zhong (2008), the climate was cold and dry implied from the negative $\delta^{13} \mathrm{C}$ and positive $\delta^{18} \mathrm{O}$ values between 9.4 to 7.4 cal ka BP. In the Megathermal Maximum (7.4-5.9 cal ka BP), more negative values of $\delta^{18} \mathrm{O}$ and gradually increased values of $\delta^{13} \mathrm{C}$ suggested the climate was warm and humid. Between 5.9 to 3.1 cal ka BP, the carbonate contents and the values of $\delta^{13} \mathrm{C}$ and $\delta^{18} \mathrm{O}$ were higher, and the particle size was coarse in the lake sediments, which suggested the climate was warm and dry with a decreased lake water level. Between 3.1 to $1.1 \mathrm{cal} \mathrm{ka} \mathrm{BP}$, the regional temperature seemed to decrease, and the humidity increased through the analysis of particle size and stable carbon and oxygen isotopes in carbonate. Since $1.1 \mathrm{cal} \mathrm{ka} \mathrm{BP,}$ there was an arid climate and a high evaporation in the Barkol Lake region.

\subsection{Hydrological changes and Holocene climate variations in southern Xinjiang}

Zhong and Shu (2001) discussed the paleoclimatic and paleohydrologic oscillations in Bosten Lake region since $12.0 \mathrm{ka}$ BP. It showed that the surface temperature of the region increased and the humidity reduced after the cold-wet Younger Dryas period. In this period, the values of $\delta^{18} \mathrm{O}$ and $\delta^{13} \mathrm{C}$ in carbonate and the contents of $\mathrm{CaCO}_{3}$ in the lake sediments increased dramatically, which suggested the lake level shrank sharply. A cold and wet peak value occurred in $8.8 \mathrm{ka}$ BP with an expanded lake area. However, the Bosten Lake region experienced several warm-dry and cold-wet climate oscillations. During the warm-humid period of 7.0 to $5.0 \mathrm{ka} \mathrm{BP}$, corresponding to Megathermal Maximum, the Bosten Lake level in- 
creased. According to the study of Zhang et al. (2007), the temperature increased between 8100 to 6400 a BP and the lake expanded. In this period, the climate was warm and humid, and the lake level was highest. Since $3.8 \mathrm{ka} \mathrm{BP}$, the warming and drying trend enhanced significantly, and then the lake shrank. Based on the reconstruction to lake evolution (Chen et al., 2006), the modern Bosten Lake formed before $8.4 \mathrm{ka}$ BP, which showed the beginning of a humid climate. During the period of 6.0 to $1.5 \mathrm{cal} \mathrm{ka} \mathrm{BP}$, the region humidity increased and the lake water level was high, which was inferred from the pollen $\mathrm{A} / \mathrm{C}$ index and Pediasrtum algae in the lake sediment.

After the cold-wet Younger Dryas period in Lop Nur region (Zhong et al., 2005; Luo et al., 2008), the climate entered a new stage. From the view of the whole Quaternary, the main trend was warm and dry during the Holocene (Liu et al., 2003). Specially, according to the study of the lake terraces (Wang et al., 2008), the lake level was high in Holocene Megathermal Maximum (7.0-7.5 ka BP), which implied a warm and wet climate.

\section{Climatic and lake environmental cha- nges in the past 1000 years}

In order to temporally extend short term $(<150$ years $)$ instrumental records of climate variability and to aid the projection of future climate, it becomes important to develop multi-proxy records of climate change of the past $2 \mathrm{ka}$. By analyzing environmental proxies, such as $\delta^{13} \mathrm{C}$ and $\delta^{18} \mathrm{O}$ in ostracode shell, and $\delta^{13} \mathrm{C}$ in organic matter, the five periods of climatic variation in Ebinur Lake region in the last 1,500 years were identified: the warm and dry interval between ca. $500 \mathrm{AD}$ and ca. $660 \mathrm{AD}$, the warm and wet stage between ca. $760 \mathrm{AD}$ and ca. $1050 \mathrm{AD}$, corresponding to the Medieval Warm Period (MWP), the warm-dry stage between ca. $1150 \mathrm{AD}$ and ca. $1500 \mathrm{AD}$, the cold and wet interval between ca. $1500 \mathrm{AD}$ and ca. $1850 \mathrm{AD}$ (i.e. the Little Ice Age) and the present warm and dry stage since ca. $1940 \mathrm{AD}$ (Wu et al., 2004).

According to the study of Chen et al. (2007), the climate of the Bosten Lake region was dry between 1000 to $1500 \mathrm{AD}$, humid in the Little Ice Age (ca. 1500-1900 AD), and was warm-dry after $1900 \mathrm{AD}$. Especially in the Little Ace Age (LIA), all the proxies changed significantly, which resulted from the increased precipitation, pollen $\mathrm{A} / \mathrm{C}$ ratios and pollen concentrations, and the decreased carbonate content and sediment's grain size.

Based on the comparisons between the environmental proxy data from Ebinur Lake and Bosten Lake, the climate change in northwestern China during the past 1,000 years was characterized by oscillations between warm-dry and cold-humid climate conditions on centennial timescales. It can be concluded that the climate was humid during the LIA, which followed a dry climate since $1900 \mathrm{AD}$.

\section{Lake hydrology variation during the period of instrumental record}

In the past century, the impacts of human activities on environmental change had experienced a process from weakness to intension. In recent 50 years, the human activities dominated the lake evolution. The lake shrank rapidly even dry up, which produced important influences on the coordinated development of regional ecology and environment as well as the sustainable development. In this section, based on previous studies and existing research results, we will focus on the lake evolutions and their impacting factors in recent 50 years.

Ebinur Lake had a surface area of $1,070 \mathrm{~km}^{2}$ in 1950 (Fig. 1), but has shrunk considerably, because of sustained increase of water which is used as irrigation. In 1972, the lake area decreased to $589 \mathrm{~km}^{2}$. Between 1972 to 1983 , the declined trend was weakened because the increased flow of the Bortala River. In the late 1990s, Ebinur Lake's area enlarged due to enhanced river inflow and the reduced water for agricultural irrigation. But the lake area shrank sharply from 2004 because of the arid climate. In 2006, the lake area was $550 \mathrm{~km}^{2}$ (Sha et al., 2006) (Fig. 2).

Manas Lake also experienced a similar process. Because of large-scale agricultural development in Manas basin (Cheng et al., 2005) and a number of water conservancy projects in the middle reaches of Manas River, Manas Lake dried completely in 1976 (Yao et al., 2007, 2010). In 1999, Manas Lake expanded to $475 \mathrm{~km}^{2}$ due to the reservoir's dam break caused by flood (Cheng et al., 2005). In 2001, the Manas River flow increased, which led to a short-term 
expansion of Manas Lake with an area of $221 \mathrm{~km}^{2}$ in 2003, after that, the lake area shrank. In 2004, the lake area was $100 \mathrm{~km}^{2}$ (Li et al., 2007; Yao et al., 2007) (Fig. 3).

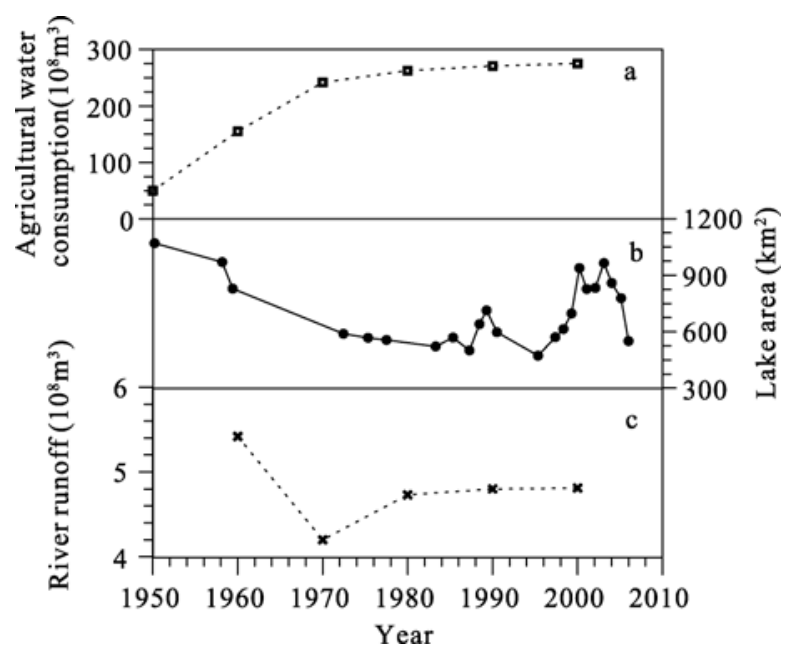

Fig. 2 Relationships between the fluctuation of Ebinur Lake area (b), agricultural water consumption of the catchment (a) and the runoff of Bortala River (c)

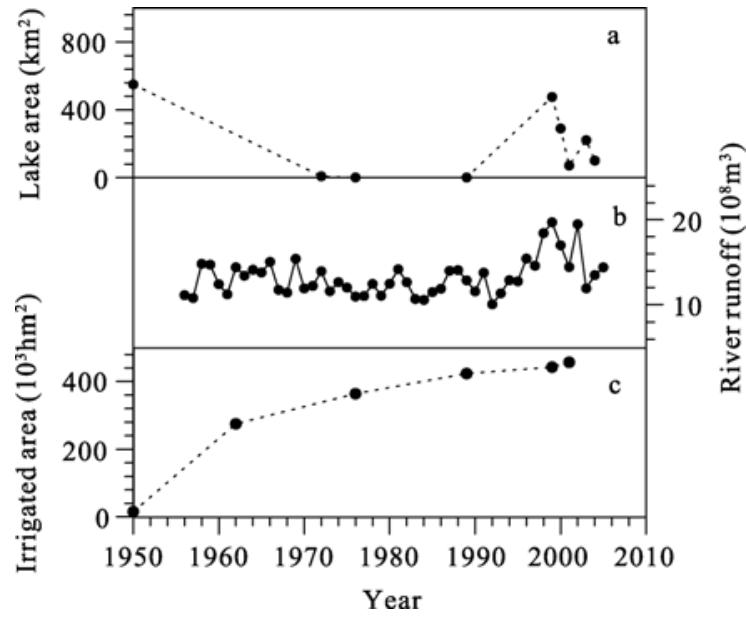

Fig. 3 Relationships between fluctuation of Manas Lake surface area (a), irrigated area of the catchment (c) and runoff of Manas River (b)

The Bosten Lake water level declined from 1,048 m in 1958 to $1,045 \mathrm{~m}$ in 1987 , because the agriculture water demand increased due to the Yanqi Basin exploitation and the river runoff's decrease (Gao et al., 2005). Since 1988, the precipitation and river runoff increased, and the agriculture water demand decreased, so that the lake water level reached up to $1,048.9 \mathrm{~m}$ in 2002. Since 2003, because the decrease of the regional precipitation and river runoff, the lake water level decline to $1,046.67 \mathrm{~m}$ in 2006 (Yuan and Yang, 2008) (Fig. 4).

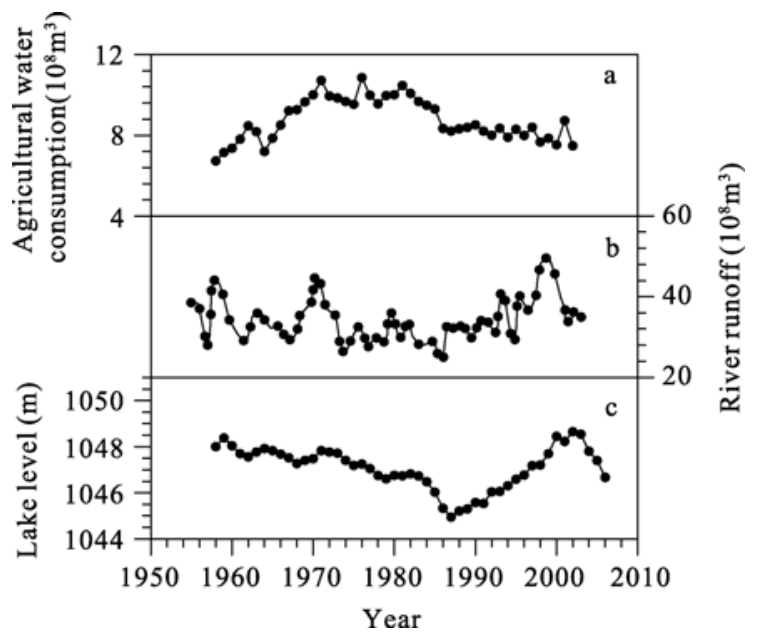

Fig. 4 Relationships between fluctuation of Bosten Lake water level (c), agricultural water demand of the catchment (a) and runoff of Kaidu River (b)

According to the changes of regional climate and human activity patterns, the environmental change of Ulungur Lake can be divided into four periods. The first period was from 1959 to 1969 with the rapid increase in human activities. Because of the reduction of lake input amount induced by water consumption of the drainage exploitation, the lake level decreased from $482.8 \mathrm{~m}$ to $480 \mathrm{~m}$. The period from 1970 to 1986 was the second stage. In this period, despite of the reduced water consumption, the water runoff of Ulungur Lake was also reduced, which made water level decrease to $478.6 \mathrm{~m}$ in 1986 (Qin, 1992). Recently, the runoff of Ulungur River decreased rapidly, which caused Ulungur Lake level decline to $468 \mathrm{~m}$ in 2005(CPPCC Xinjiang Uygur Autonomous Regional Committee, 2005) (Fig. 5).

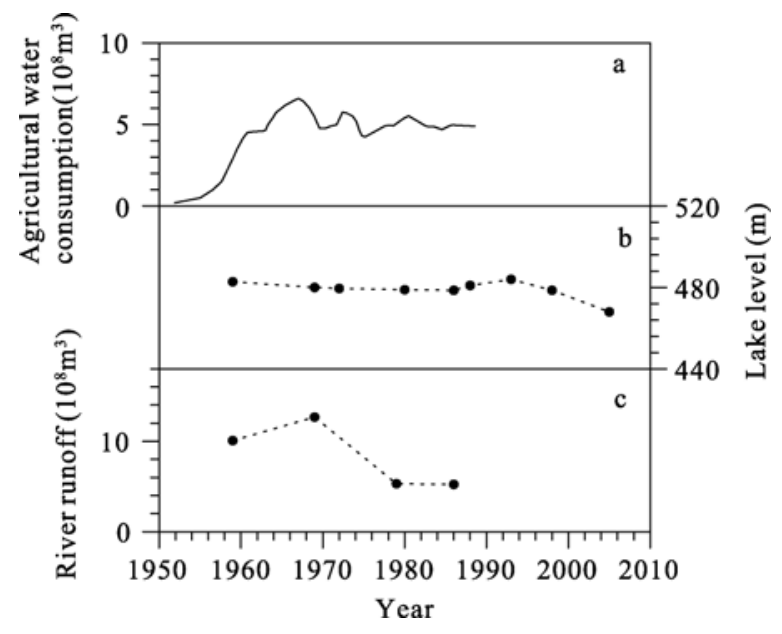

Fig. 5 Relationships between fluctuation of Ulungur Lake water level (b), agricultural water demand of the catchment (a) and flux of Ulungur River (c) 
In general, although some problems existed in the paleoclimate studies, such as the constructions of age-depth model, the selection and explanation of paleoenvironmental proxies and so on, the climate is currently in the warm and dry stage. In the process of the lake evolution from the instrumental data, the lake water level declined sharply due to the large scale agriculture exploitation. In 1980s, the climate was better, resulting in the lake water level temporarily to rise. But in recent years, the lake had a decline tendency again.

\section{Lake area variations and their enviro- nmental responses}

In the natural history, the environmental impacts of the shrinking lakes are recorded in lake sediment faithfully. In the Ebinur Lake sediment, there are three "burning layers" (corresponding to thermoluminescence dating 6600 a BP, 1600 a BP and less than 30 a $\mathrm{BP})$ with lots of silty sand, which reflected the dry climate and the blown sand activities (Wen, 1990). In recent 50 years, the lake water level declined sharply due to human activities, which had a tremendous effect on the daily life and productive work of people. The influences are as follows:

(1) Oasis desertification. The dry lake floor turned into barren and then became a new sand source. Simultaneously, a new desert was formed by the water table descending, vegetation degradation, grassland desertification and blown sand disaster by wind from the dry lake floor and nearby desert (Jilili et al., 2010). The changed underlying surface influenced the lake adjusting climate functions and the human dwelling environments.

(2) Because of the lakefront and marsh vanishing and lake water salinization, the local residents lost some economic income sources, such as marsh and fishery resources. Therefore, the pollute dust derived from the uncovered lake floor impacted the agriculture and animal husbandry production under the leeward regions. In addition, the pollute air and drinking water threatened the aborigines' health directly.

(3) The degeneration of regional climate. The lakes in arid areas are not only important water resources but also irreplaceable environmental resources. The water in the lakes keeps the steady temperature of the region by absorbing heat in summer and giving off heat in winter, which reduced the possibility of bad weather. For example, because the Bosten Lake has a clear regulatory role to regional climate, the wet island effect is obvious (Zhou et al., 2001). The declining water level and shrinking water area will induce the changes of underlying surface, which affects water and heat exchange, and then weaken the function of climate regulation.

\section{Discussion and conclusion}

There are some differences in Holocene climate changes between northern and southern Xinjiang. In northern Xinjiang, the climate was dry in early Holocene, warm and wet in early Mid-Holocene, dry in late Mid-Holocene, wet in early late-Holocene and dry in the late. In southern Xinjiang, researchers focused on the Lop Nur and Bosten Lake. Despite environmental proxy data from different researchers reflected some different characteristics of regional climate, the climate of Holocene Megathermal Maximum was warm and wet recorded in lake sediments. Li (1990) suggested that the strengthened Asian summer monsoon penetrated into arid central Asia, which caused the wet climate in Holocene Megathermal Maximum. Chen et al. (2006) proposed that the pattern of Holocene effective-moisture evolution in the westerly dominated arid central Asia was mainly determined by North Atlantic sea-surface temperatures and high-latitude air temperatures that affected the availability, the amount and transport of water vapor. On a century-time scale, the climatic pattern in Xinjiang was expressed as the combination of warm-dry and cold-wet climate. Based on the analysis of the Ebinur Lake sediment, possibly, Xinjiang was influenced by weaker monsoon climate. In the cold period, the westerly from Atlantic Ocean moved to south, which brought more vapor to Xinjiang.

The paleoenvironmental change of the lakes can be seen as natural process without the influences of human activities, which can provide a reference to evaluate future lake evolution. The Ebinur Lake area shrank from $2,330 \mathrm{~km}^{2}$ in $4.5 \mathrm{ka} \mathrm{BP}$ to $1,340 \mathrm{~km}^{2}$, but with only 30 years, the lake area shrank from 1,070 $\mathrm{km}^{2}$ in 1970 to $550 \mathrm{~km}^{2}$ in 2006. In the perspective of natural history, the shrinkage and enlargement of the 
lakes reflected the climate oscillation. The lake shrinkage is inevitable in Xinjiang due to the arid climate. But since 1950s, the lake area shrank sharply which is induced by large-scale agricultural and industrial water demands. The improvement of regional climate conditions significantly increased the lake water levels in Xinjiang since 1980s which was proposed by Shi et al. (2003) as the transition of warm-humid climate. According to climatic factors and human activities, the lakes will continue to shrink in Xinjiang.

The lake ecology is constrained by unique hydrology, geomorphology and climatic conditions in arid areas. The ecosystem is extremely fragile, and the abilities to resist disturbance and to regenerate are weak. Once the ecosystem is damaged, it is hard to restore for a long period of time. The declined lake water level will bring a series of regional environ-

\section{References}

Chen F H, Huang X Z, Yang M L, et al. 2006. Westerly dominated Holocene climate model in arid central Asia-a case study on Bosten Lake, Xinjiang, China. Quaternary Sciences, 26(6): 881-887.

Chen F H, Huang X Z, Zhang J W, et al. 2007. Humid little ice age in arid central Asia documented by Bosten Lake, Xinjiang. Science in China Series D, 37(1): 77-85.

Cheng W M, Zhou C H, Liu H J, et al. 2005. The oasis expansion and eco-environment change over the last 50 years in Manas River Valley, Xinjiang. Science in China Series D, 35(11): 1074-1086.

CPPCC Xinjiang Uygur Autonomous Regional Committee. 2005. BuluntuhaiLake. [2005-12-15].http://www.xjzx.gov.cn/showcontent. asp? $\mathrm{id}=330 \&$ Nclassid $=145$.

Engstrom D R, Wright J H E. 1984. Chemical stratigraphy of lake sediments as a record of environmental change. In: Haworth E Y, Lund J W G. Lake Sediments and Environmental History. Minneapolis: University of Minnesota Press, 11-67.

Gao H Z, Zhu C, Li Z Y. 2005. Quantitative analysis of the impact of irrigation water from Kaidu River on the area change of Bosten Lake. Journal of Natural Resources, 20(4): 502-507.

Han S T, Qu Z. 1992. Inner terrestrial Holocene climate of Balikun lake in northen Xinjiang. Science in China Series B, (11): 1201-1209.

Jiang Q F, Liu X Q, Shen J. 2006. Grain-size characteristics of Wulungu Lake sediments and its palaeoclimate and paleoenvironment implication. Acta Sedimentologica Sinica, 24(6): 877-882.

Jiang Q F, Shen J, Liu X Q, et al. 2007. A high-resolution climatic change since Holocene inferred from multi-proxy of lake sediment in westerly area of China. Chinese Science Bulletin, 52(9): mental problems. The utilization and protection of the lake and watershed resources have to suit to climate change and to be based on natural resource's carrying capacity. The utilization of natural resources also needs overall and scientific arrangement and management. Only in this way can we ensure a stable socio-economic development of regions and a sustainable utilization of natural resources, which will keep the balance of regional ecology and socio-economic systems in different climate conditions.

\section{Acknowledgements}

This study was supported by the Knowledge Innovation Program of the Chinese Academy of Sciences (KZCX2-EW-308), the National Basic Research Program of China (2006FY110600) and the National Natural Science Foundation of China (41071139 and 40971117).

\section{2-1049}

Jilili Abuduwaili, Liu D W, Wu G Y. 2010. Saline dust storms and their ecological impacts in arid regions. Journal of Arid Land, 2(2): $144-150$

Li J J. 1990. The patterns of environmental changes since late pleistocene in northwestern China. Quaternary Sciences, (3): 197-204.

Li Q F, Shi W J, Zhang L. 2007. Analysis on flood peak in the Manas river. Research of Soil and Water Conservation, 14(4): 401-403.

Lin R F, Wei K Q, Cheng Z Y, et al. 1996. A palaeoclimatic study on Lacustrine Cores from Manas Lake, Xinjiang, Western China. Geochimica, 25(1): 63-72.

Liu C L, Wang M L, Jiao P C, et al. 2003. Holocene Yellow Silt Layers and the paleoclimate event of 8200 a BP in Lop Nur, Xinjiang, NW China. Acta Geologica Sinica, 77(4): 514-518.

Liu D S, Li Z C, Ding Z L. 2004. Studies on Water Resources Allocation, Sustainable Development Strategy of Ecological Environment Improvement in the Northwest Region (natural history). Beijing: Science Press, 5-21.

Luo C, Peng Z C, Yang D, et al. 2008. Paleoclimate of Lop Nur and the response to global change by geochemical elements multi-analysis. Geochimica, 37(2): 139-148.

Qin B Q. 1992. Analysis the impact of climate change and human activity on the lake Wurengu. Arid Land Geography, 15(1): 10-16.

Rhodes T E, Gasse F, Li R F, et al. 1996. A late Pleistocene-Holocene lacustrine record from Lake Manas, Zunggar (northern Xinjiang, western China). Palaeogeography, Palaeoclimatology, Palaeoecology, 120(1-2): 105-121. 
Sha Y, Li C, Cheng A, et al. 2006. Recently-dried-up lake bed of the Ebinur Lake in large area. Arid Land Geography, 29(4): 616.

Shi Y F, Shen Y P, Li D L, et al. 2003. Discussion on the present climate change from warm-dry to warm-wet in northwest China. Quaternary Sciences, 23(2): 152-164.

Stanley S. 2000. The past climate change heats up. Proceedings of the National Academy of Sciences of the United States of America, 97(4): 1319.

Sun X J, Du N Q, Weng C Y, et al. 1994. Paleovegetation and paleoenvironment of Manas Lake, Xinjiang, NW China during the last 14000 years. Quaternary Sciences, (3): 239-248.

Wang F B, Ma C M, Xia X C, et al. 2008. Environmental evolution in Lop Nur since late pleistocene and its response to the global changes. Quaternary Sciences, 28(1): 150-153.

Wang S M, Dou H S. 1998. A Directory of Lakes in China. Beijing: Science Press, 557-561.

Wen Q Z. 1990. Preliminary probe of climatic sequence in the last 13,000 years in Xinjiang Region. Quaternary Sciences, (4): 363-371.

Wu J L. 1995. Characters of the evolution of climate and environment during the last $10 \mathrm{ka}$ years in Aibi Lake region, Xinjiang. Scientia Geographica Sinica, 15(1): 39-46.

Wu J L, Shen J, Wang S M, et al. 2003. Characteristics of an early Holocene climate and environment from lake sediments in Ebinur region, NW China. Science in China (Earth Sciences), 33(6): 75-81.

Wu J L, Liu J J, Wang S M. 2004. Climatic change record from stable isotopes in lake Aibi, Xinjing during the past 1500 years. Quarternary Sciences, 24(5): 585-590.

Wu J L, Yu Z C, Zeng H, et al. 2009. Possible solar forcing of 400-year wet-dry climate cycles in northwestern China. Climate Change, 96(4): $473-482$.
Xiao X Y, Jiang Q F, Liu X Q, et al. 2006. High resolution sporopollen record and environmental change since Holocene in the Wulungu Lake, Xinjiang. Acta Micropalaeontologica Sinica, 23(1): 77-86.

Xue J B, Zhong W. 2008. Holocene climate change recorded by lacustrine sedimets in Barkol Lake and its regional comparison. Quaternary Sciences, 28(4): 610-620.

Yang X D, Wang S M. 1994. Pollen assemblage and environmental changes in the last 12000 years in Wulungu Lake. Arid Zone Research, 11(2): 7-10.

Yao Y H, Wang X Q, Zhou C H, et al. 2007. Changes of Manas Lake in the past 50 years in Xinjiang Province. Advances in Water Science, 18(1): 17-23.

Yao Y H, Li H G. 2010. Tectonic geomorphological characteristics for evolution of the Manas Lake. Journal of Arid Land, 2(2):167-173.

Yuan X, Yang D H. 2008. Study on the aqueous environment problems of the Bosten Lake, Xinjiang. Arid Zone Research, 25(2): 735-740.

Zhang C J, Zheng M P, Prokopenko A, et al. 2007. The palaeoencironmental variation from the high-resolution record of the Holocene sediment carbonate and isotopic composition in Bosten Lake and responding to glacial activity. Acta Geologica Sinica, 81(12): 1658-1671.

Zhong W, Shu Q. 2001. Palaeoclimatic and palaeohydrologic oscillations since about $12.0 \mathrm{ka} \mathrm{BP}$ at Bosten Lake, southern Xinjiang. Oceanologia et Limnologia Sinica, 32(2): 213-220.

Zhong W, Tuerxun, Keyimu, et al. 2005. Paleoclimatic and paleoenvironmental evolution since about $25 \mathrm{ka} \mathrm{BP}$ in the Taitema Lake area, south Xinjiang. Arid Land Geography, 28(2): 183-187.

Zhou C H, Luo G P, Li C, et al. 2001. Environmental change in Bosten Lake and its relation with the oasis reclamation in Yanqi Basin. Geographical Research, 20(1): 14-23. 